\title{
NARKOBA: BAHAYA PENYALAGUNAAN DAN PENCEGAHANNYA
}

\author{
Veronika Todo \\ Institut ilmu kesehatan IIK Starada Indonesia \\ veronikatodo1@gmail.com
}

\begin{abstract}
Abstrak
Narcotic abuse over children should get more attention and concern from all instrument of society including family, social institution and government. So far, the network of narcotic market driven by a latent syndicate that has consumer target 14 to 18 years old children who still have an unstable attitude. This condition might hazard Indonesian youth because they are the next generation who will develop this country in the future. So, this is an urgent step to prevent the drugconsumption among children and destroy its syndicate in order to save and secure this nation. This paper provide description abaut the danger of drug and how to $\mathrm{p}$ revent children not to consume it.
\end{abstract}

\section{A. Latar Belakang}

Tulisan ini bersumber dari berbagai buku yang diterbitkan oleh badan narkotika nasional (BNN), sehingga banyak materi yang merupakan kutipan langsung dari buku tersebut. Tujuan penulisan ini tidak lain ikut serta mensosialisasikan program BNN melakukan kegiatan advokasi pencegahan, pemberantasan penyalagunaan dan peredaran gelap narkoba (P4GN).

Narkoba sudah menjadi istilah popular di masyarakat, namun masih sedikit yang memahami arti narkoba. Narkoba merupakan singkatan dari narkotika, psikotropika dan bahan aktif lainnya. Dalam arti luas, adalah obat, bahan atau zat. Bila zat ini masuk dalam tubuh manusia, baik secara oral (melalui mulut), atau di hirup maupun melalui alat suntik akan berpengaruh pada kerja otak atau susunan saraf pusat. Narkotika memiliki daya adiksi ( ketagihan), daya toleran ( penyesuaian), daya habitual ( kebiasaan) yang sangat kuat, sehingga menyebabkan pemakai narkotika tidak dapat lepas dari pemakaiannya. Dibawah ini akan di sampaikan berbagai jenis narkotika. Berdasarkan cara pembuatannya, narkotika dibedakan kedalam 3 golongan, yaitu narkotika alami, semintesis, dan narkotika sintesis.

Narkotika alami merupakan narkotika yang zat adiktifnya di amil dari tumbuh tumbuhan,contohnya : ganja merupakan tanaman perlu dengan daun menyerupai singkong yang tepinya bergerigi dan berbulu halus. Jumlah jarinya selalu ganjil 5,7,9, Indonesia merupakan daerah subur untuk tanaman ganja. Cara penyalagunaan ganja ini dengan di keringkan dan di campur dengan tembakau rokok atau di jadikan rokok lalu di bakar serta di hisap. Hasil merupakan tanaman 
serupa ganja yang tumbuh di amerika latin dan eropa, proseses pematanganya dengan suling sehingga berbentuk cair. Koka adalah tanaman perdu mirip pohon kopi . buahnya yang matang akan berwarna merah seperti biji kopi. Koka ini kemudian di olah menjadi kokain. Opium merupakan bunga dengan bentuk dan warnah yang indah . dari geta bunga opium dihasilkan candu.opium banyak tumbuh di anatara Burma, kamboja dan Thailand, juga didaerah antara Afganistan, iran dan pakitan.

Narkotika semisintesis adalah narkotika alami yang di olah dan di ambil zat aktifnya agar memiliki khasiat yang lebih kuat sehingga bisa dimanfaatkan untuk kepentingan dunia kedokteran, contohnya: morfin, biasa di pakai dunia kedokteran untuk menghilangkan rasa sakit atau pembiusan pada suatu operasi. Kodein, dipakai untuk penghilang batuk. Heroin, tidak dapat di pakai dalam pengobatan karena daya adiktifnya sangat besar dan manfaatnya secara medis belum di temukan. Dalam perdagangan gelap, heroin di beri nama putaw, atau petai. Bentuknya seperti tepung terigu: halis, putih dan agak kotor .

Narkotika sintesis adalah narkotika palsu yang dibuat dari bahan kimia.narkotika ini digunakan untuk pembiusan dan pengobatan bagi orang yang menderita ketergantungan narkoba (substitusi) contohnya: petidin, untuk obat bius lokal: metadhon, untuk pengobatan pecandu narkoba : Naltrexon untuk pengobatan pecandu narkoba.

Psikotropika merupakan zat atau obat bukan narkotika, baik alamiah maupun sintesis, yang memiliki khasiat Psikoaktif melalui pengaruh selektif pada susunan saraf pusat yang menyebabkan perubahan khas pada aktifitas norman pada perilaku. Psikotropika adalah obat yang digunakan oleh dokter untyk mengobati gangguan jiwa. Berdasarkan ilmu farmo kologi, psikotropika di kelompokan kedalam 3 golongan: depresan, stimulant, dan halusinogen.

1. Kelompok depresan/penekan syaraf pusat (penenang atau obat tidur). Contohnya adalah valium, BK, rahipnol, mogadon dan lain-lain. Jika diminum, obat ini memberikan rasa tenang, mengantuk, terteram, damai. Obat ini juga menghilangkan rasa takut dan gelisa.

2. Kelompok stimulant/perangsang syraf pusat (anti tidur). Contohnya adalah amfetamin, ekstasi, dan shabu. Ekstasi berbentuk tablet beraneka bentuk dan warna. Amfetamin berbentuk tablet berwarna putih. Bila diminum, obat ini mendatangkan rasa gembira, hilangnya rasa permusukan, hilangnya rasa marah, ingin selalu aktif, badan terasa fit, dan tidak merasa lapar. Daya kerja otak menjadi serba cepat, namun kurang terkendali. Shabu berbentuk tepung Kristal kasar berwarna putih bersih seperti garam

3. Kelompok halusinogen, yaitu obat, zat, tanaman, makanan atau minuman yang dapat menimbulkan khayalanan. Contohnya adalah LSD (Lysergic Acid diethyltamide), getah tanaman kaktus, kecubung, camur tertentu dan ganja.

Bahan adiktif lainnya, adalah zat-zat selain narkotika dan psikotropika yang dapat menimbulkan ketergantungan. Contohnya: rokok, kelompok alcohol dan 
minum lain yang dapat memabukkan dan menimbulkan ketagihan, thinner dan zat-zat lainnya seperti lem kayu, penghapus cair, aseton, cat, bensin, yang bila dihisap, dihirup, dan dicium dapat memabukkan. Jadi rokok, alcohol, serta zat-zat lain yang memabukkan dan menimbulkan ketagihan juga tergolong narkoba.

B. 1. Bahaya narkoba

\section{PEMBAHASAN}

Persoalan narkoba merupakan persoaalan yang harus di tangani secara sunggusunggu oleh seluruh kelompok masyarakat. Bukan saja penanganan bagi penggunannya, melainkan juga perkembangan bisnis narkoba yang di Indonesia sudah mulai menggelisahkan. Bagaimana pemerintah dan aparat penegak hukum melalui BNN juga memberantas pengedar dan produsennya. Kita tidak ingin di kemudian hari Negara kita di kuasai oleh kartel-kartel narkoba seperti yang terjadi di beberapa Negara amerika latin.

Dalam narkoba terkandung 3 sifat yang sangat jahat dan berbahaya yaitu habitual, adiktif dan toleran. Habitual merupakan sifat pada narkoba yang membuat pemakainya akan selalu teringat, terkenang dan terbayang sehingga cenderung untuk selalu mencari dan rindu untuk terus memakai narkoba. Adiktif merupakan sifat narkoba yang membuat pemakainya terpaksa memakai terus dan tidak dapat menghentikannya. Penghentian atau pengurangan pemakaian narkoba akan menimbulkan "efek putus zat" atau " withdrawal effect", yaitu perasaan sakit luar biasa, atau "sakaw". Penderita yang mengalami sakaw itu biasanya mengatasi rasa sakitnya melalui 2 cara :

1. Kembali mengkonsumsi jenis narkoba yang sama orang ini seperti ini disebut

"junkies", atau pemadat atau pecandu. Bila sedang memakai narkoba orang tersebut Nampak normal, tetapi bila sedang tidak memakai Nampak gelisah, tidak normal, lesu, gelisah, tidak fit dan tidak percaya diri

2. Bila tidak kembali memakai tetapi juga tidak tahan rasa sakit, orang tersebut akhirnya mencari jalan pintas, yaitu bunuh diri.

Toleran merupakan sifat narkoba yang membuat tubuh pemakainya semakin lama semakin menyatu dengan narkoba dan menyesuaikan diri dengan narkoba itu sehingga menuntut dosis pemakaian yang semakin tinggi. Bila dosisnya tidak di naikkan, narkoba itu tidak akan bereaksi, tetapi akan membuat pemakainya mengalami sakaw . maka dosis pemakaiannya harus sama dengan dosis pemakaian sebelumnya.

Bila dilihat pada kerusakan dan perubahan sikap maka pecandu narkoba akan mengalami perubahan yang justru bisa membahayakan diri dan lingkungan yaitu:

1. Tergila-gila pada narkoba lebih mencintai narkoba dari pada diri sendiri, orang tua dan saudara-saudaranya.

2. Sulit melepaskan diri dari jerat narkoba,karena akan mengalami penderitaan luar biasa ( sakaw)

3. Dosis pemakaian akan bertambah banyak, sehingga kematian menjemput. 
4. Sifat dan sikap berubah menjadi eksklusif, egois, sombong, asocial, dan jahat ( psikosis).

5. Mengalami kerusakan organ tubuh ( hati, paru-paru, ginjal, otak adan lainlain)

6. Terjangkit penyakit memamtikan( HIV/AIDS, sifilis dan sebagainya).

\section{PENCEGAHAN}

Mencegah peredaran narkoba dengan melindungi anggota masyarakat yang belum tersentuh narkoba merupakan prioritas yang harus di lakuakan olehmasyarakat tanpa terkecuali. Selama ini BNN merancang berbagai kegiatan pencegah yaitu : promotif, program ini ditunjukkan kepada masyarakat yang belum memakai narkoba, atau bahkan belum mengenal sama sekali. Prinsinya dengan meningkatkan peranan sejahtera, sehingga tidak sempat berfikir untuk memakai narkoba. Prefentif, melalui kegiatan: kompanye antipenyalagunaan narkoba; penyuluhan seluk beluk narkoba; pendidikan dan pelatihan kelompok sebaya ( pers group); upaya mengawasi dan mengendalikan produksi dan distribusi narkoba dimasyarakat.

Advokasi dan KIE juga merupakan bentuk komunkasi yang dilaksanakana sebagai salah satu bentuk program pencegahan. Advokasi merupakan rangkaian bentuk rangkaian komunikasi strategis yang di rancang secara sistematis dan di laksanakan( waktu tertentu baik oleh indivudu maupun kelompok, dengan memaksud agar membuat keputusan, membuat kebijakan public menguntungkan bagi kelompok masyarakat marjinal. Kegiatan advokasi juga di maksudkan untuk memberi pencerahan dan pemberdayaan bagi kelompok marjinal dan menumbuhkan kearifan dikalangan masyarakat, agar mendukung kebijakan publik tersbut. KIE merupakan bentuk komunikasi yang di laksanakan oleh profider program agar sasaran (individu, keluarga dan masyarakat) menerima program yang ditawarkan dan melaksanakan perilaku yang di tawarkan. Advokasi merupakan aksi, perubahan, dan komitmen sedangkan KIE sebagai suatu proses interfensi terencana yang menggabungakan pesan-pesan informasional, pendidikan dan motifasional, untuk mencapai perubahan pengetahuan, sikap dan perilaku yang dapat di ukur. Dukungan stakeholderstakeholder juga di perlukan untuk melaksanakan program ini.

Bila di perhatikan lebih saksama, penanganan persoalan narkoba bukan saja dominasi pemerintah melalui BNN dan aparat penegak hukum, tetapi lebih kepada dukungan masyarakat luas. Partisipasi masyarakat sangat di perlukan untuk mengawasi lingkungan sekitar tempat tinggalnya, lingkungan sekolah, komunikasi antara orang tua dan anak yang harmonis tentu sangat penting. Keterbukaan antara BNN dengan semua masyarakat untuk membuka informasi seputar narkoba, sehingga menghilangkan kesenjangan kepentingan.

\section{PENUP}


Korban narkoba kini bukan lagi dominan orang berduit atau artis, tetapi suda menjama hapir seluruh lapisan masyarakat terutama anak-anak usia sekolah antara 14-18 tahun merupaka usia rawan mencicip nrkoba. Narkoba bisa dating dengan cara sangat halus, melalui rayuan pemasaran yang dekat dengan nilai kebanggaan yang ada pada golongan muda, agen-agen pemasaran nya telah membangun jaringan luas dan bersifat terputus yaitu antar satu Bandar dengan Bandar lain terkadang tidak saling mengenal. Berbagai geng yang kini mulai merambah kota-kota kecil, nampaknya potensial terupakan kelompok user narkoba, sebab mereka juga potensial menggunakan rorok dan minuman alkol.

Orientasi yang merusak merupakan dorongan untuk melakukan kegiatan kekerasan dan criminal terlebihih bila geng-geng tersebut diarganisasi oleh otak criminal yang berintensi bisnis criminal, makan potensi merusaknya melebihi kelompok atau orang yang melaukan tindakan kriminila sekedar untuk makan. Sistim pendidikan kita, yang leh berolrientasi membangun masyarakat berbasis industry kapitalis, harus dilengkapi dengan kurikulum yang berbasis etika moral memperkuat karakter bangsa.

\section{Daftar Pustaka}

BNN, Petunjuk Teknis Advokasi Bidang Pencegahan Penyalagunaan Narkoba, 2008

BNN dan Puslitkes UI.Survey Nasionsl Penyalagunaan dan Peredaran Gelap Narkoba di Indonesia, 2010 